\title{
The Politics of Literature and Literacy: Popular Song Writing and Proletarian Poetry in Post-Revolutionary France
}

\author{
Steven E. Rowe
}

\begin{abstract}
This essay examines the politics of song writing and singing in working-class singing societies in Paris, known as goguettes, in the early nineteenth century. The practices of writing and singing songs in these societies defined the relationships among participants by equality and good feelings, resisting the hierarchy and domination of the laissez-faire social order. At the same time, these song-writing and singing practices also produced symbolic forms of masculine authority and domination - placing working-class women in positions of subordination. By analyzing this complex politics of writing in this particular case of the goguettes, this essay argues for recovering working-class writings as significant sources for historians of literacy, and for examining the historically specific social and political contexts for the production of specific forms of writing and reading as a way of studying the historical meanings of literacy.
\end{abstract}

\section{RÉSUMÉ}

Cet article s'intéresse à la composition et à l'interprétation de chansons de la classe ouvrière parisienne, notamment dans les goguettes, au début du XIX siècle quant à leur portée sociale et politique. Les manières d'écrire et de chanter dans ces milieux populaires décrivent les relations sociales parmi la clientèle où égalité et bons sentiments réfutent toute forme de hiérarchie et où l'on prône une attitude de laissez-faire. De même, le texte et l'interprétation de ces chansons populaires expriment de manière symbolique l'autorité et de la domination masculine, situant la femme de la classe ouvrière dans une position de subordination. Par l'analyse de la complexité des pratiques d'écriture des chansons, particulièrement celles des goguettes, cet article soutient que les écrits populaires constituent une source significative pour les historiens de la littérature et permet d'apprécier le contexte social et historique de cette époque.

Ne voulant être de sa vie

Ni courtisé ni courtisan,

Mon père vécut sans envie

En honnête et simple artisan;

Au gai mortel, dont je tiens l'être,

De ressembler je me prévaux,

Et sentant tout ce que je vaux, Je vis sans esclave et sans maittre.
Not wanting to make of his life

Neither a flatterer nor sycophant,

My father lived without envy

As an honest and simple artisan;

To the happy mortal, whom I take after,

I take pride in resembling

And sensing everything that I am worth,

I live without a slave and without a master. ${ }^{1}$ 
So began the song "L'Artisan" ("The Artisan"), written by a painter named Dauphin and published in one of the earliest printed collections of songs from the popular singing societies known as goguettes, which became quite numerous in Paris in the 1820s. The song collection in which "L'Artisan" appeared was edited by Emile Debraux, a wellknown participant in these singing societies. Debraux included songs by twenty-five different authors, most of whom contributed one or two songs. While "L'Artisan" celebrates artisanal work and life by depicting it in idealized terms, other songs in the volume varied widely in their content, from fairly traditional songs about love and wine to songs about the goguettes themselves. When assessing the impact of the goguettes and the variety of songs sung in these societies, one contemporary observer noted that "the goguette was a school for the people. The songs produced there each reflected the thoughts of its author." 2 These "schools" were sites for the learning and practice of literacy, leading to the development of specific forms of writing and reading centered around the production of songs.

Performed in the midst of the participants in the "school," often read by the singer and sometimes written during the goguette meeting, these songs are not only evidence of literacy in a specific social context but also are specific literary products particular to early nineteenth-century France. As such, they resemble the working-class poetry that appeared in print slightly later, such as in the 378-page volume titled Les Poètes du Peuple au XIX $X^{e}$ siècle, edited and published by Alphonse Viollet in $1846 .{ }^{3}$ Viollet was an author, editor, and translator of a wide range of books on subjects ranging from comparative studies of world religions to various works of history. In Les Poètes du Peuple, Viollet included selections of poetry from twenty-one different authors, most of whom were working-class men (only three were women), along with very brief biographical sketches introducing each author as well as some commentary on particular poems. In his introduction, Viollet claims that he selected poets "from France's diverse provinces," and while four poets hailed from Paris, and many more from northern France more generally, the diversity of the poets' locales and of the trades they practiced is striking. The range of workers' poetry makes Viollet's text stand out, suggesting fairly widespread practices of poetry writing among the working class throughout France in the 1840s.

Viollet was not, however, the first to publish French workers' poetry, nor were the works of all the poets represented in his text appearing in print for the first time. Both the weaver Magu and the stonemason Charles Poncy had previously published their own poetry, with the patronage of the well-known writer George Sand. ${ }^{5}$ Sand also helped other workers publish their poetry, such as the locksmith Jérôme-Pierre Gilland. ${ }^{6}$ Still other workers found additional outlets for publishing their poetry, including soliciting subscriptions for self-published texts or publishing short collections that could be sold by peddlers and traveling booksellers. Most of these publications of workers' poetry did not appear until the late 1830 s and early 1840 s, suggesting a new literary phenomenon was emerging in France.

Even with the diversity of working-class writers publishing poetry by this time, the output of workers' poetry paled in comparison to the numbers of songs produced by participants in goguettes from the 1820 s to the 1850 s, as well as to the numbers of the participants themselves. If the goguettes were "schools for the people," these "schools" and 
their participants tell a more significant story for examining the history of popular literacy and literature in nineteenth-century France than does workers' poetry. On the other hand, the line between "songs" and "poetry" was not as clearly demarcated as it is today, particularly in the literary output of the working classes. Because of this, historians studying the working classes have examined both poetry and songs together with all forms of workers' texts, and this historiographical context needs to be illuminated. This essay begins by briefly examining this historiography, arguing that a specific methodology from literacy studies can usefully re-orient the historiographical focus on these texts as evidence for the analysis of literacy. By then applying this methodology and examining the production and performance of songs in Parisian goguettes as a way of looking at the relationships among literacy, social relations, and politics in post-Revolutionary France, we see that the writing and singing of songs in goguettes intersected with the complexities and conflicts of class and gender in early nineteenth-century France. These connections between the practices of writing and singing songs and particular formations of class and gender belie classifying the goguettes simply as "schools" or viewing working-class literacy solely as an act of resistance.

\section{Historiographical Context: Working-Class Writing and European Labour History}

Historians studying European industrial capitalism and the birth of modern labour movements have often examined texts written by workers as sources of information on working-class politics, especially militant, radical, or revolutionary political actions. ${ }^{7}$ In the case of France, social historians have studied the connections that early forms of industrialization and laissez-faire reforms had with workers' participation in large-scale insurrections, beginning with the French Revolution and continuing throughout the tumultuous nineteenth century. These studies have revealed the overwhelming participation of artisans - more-or-less skilled handicraft workers - in the radical political movements of the nineteenth century, rather than the unskilled or semi-skilled labourers often thought to represent the modern industrial proletariat. In fact, until the late nineteenth century, artisans working in "small workshop[s] or in [their] own home[s], or (as [labourers]) in more-or-less casual employment in the streets, on building-sites, on the docks" formed the core group of typical industrial workers throughout Europe, and especially in France. ${ }^{8}$ Many early labour historians argued that these workers were particularly threatened by changes in work processes brought on by early forms of industrialization, especially an increasing division of labour and frequent use of subcontracting, which led to a growing use of semi-skilled or unskilled labourers. This threat to their livelihoods and identities as workers, these historians have concluded, motivated artisans to engage in various forms of political militancy, from participation in local insurrections — such as the silk workers' revolts in 1834 Lyon — to leadership in the Revolution of $1848 .^{9}$

These conclusions about the link between industrialization, artisanal work, and workers' politics were criticized by the philosopher Jacques Rancière in the early 1980s, and, in doing so, Rancière made extensive use of French workers' writings - perhaps more so than most social historians - as evidence of their politics. Specifically, Ran- 
cière argued that militant French workers tended to be those who worked in lower-skill professions and had a certain amount of "free time" (disponibilité) due to irregular work schedules and seasonal unemployment. ${ }^{10}$ The wide-range of French workers' writings Rancière examined led directly to this critique of earlier conclusions about exactly which workers engaged in political action and why. While more precise and careful in his analysis of workers' writings than many labour historians, Rancière's overall approach to these texts is fairly similar to most historians' methods: he examines writings for statements of specific motivations behind militant action and ideas, and for a better understanding of the nature of workers' political positions.

In addition to focusing our attention on the significance of workers' texts, the debate between Rancière and social historians has also demonstrated the complexities of understanding workers' criticisms of early forms of industrial capitalism in post-Revolutionary France. As social historians have argued, workers articulated these critiques in conflicts with employers - who were either master artisans or large workshop owners - over wages (both rates of wages and how wages were paid), an increased division of labour, the use of subcontracting (marchandage), and the instability of employment. ${ }^{11}$ Most frequently, such conflicts were local, limited to a particular trade in one city, and sometimes resulted in work stoppages, as in the case of a Parisian carpenters' strike in 1845 . When workers articulated a more extensive critique of industrial labour and a broad-based identity as "workers" (as opposed to workers from a particular trade), they often built upon a language of association inherited from the corporate traditions of the old regime. ${ }^{12}$

Through the 1830 s and 1840 s, workers increasingly presented such conflicts and critiques in terms taken from early forms of socialism and communism. This is, however, where the analysis of French workers' critique of early industrial capitalism becomes difficult. Does this critique indicate some form of class consciousness, and if so, what kind of class consciousness? When did it develop, and why? Was this ultimately a politics of resistance based (1) on pride in one's work with the nature of that work under attack; (2) on alienation due to the intense physical demands of industrial work and its psychological consequences; or (3) on a sense of honour challenged by new disciplinary practices in the workplace? ${ }^{13}$ To further complicate this analysis, French workers' politics of opposition to both the regimes of the Restoration (1815-1830) and the July Monarchy (1830-1848) were not solely based on critiques of economic and social changes but were influenced by a continued fascination with Napoleon and by radical republicanism — both inherited from the French Revolution. ${ }^{14}$ Ultimately, it appears that the best conclusions one can reach is that workers engaged in complex, multi-layered critiques of the organization and nature of labour in nineteenth-century France and of the consequences of the laissez-faire social order for workers, including poverty, frequent unemployment, and debt. ${ }^{15}$

Rather than attempt to answer these questions raised by the work of Rancière and labour historians, more recent studies of working-class politics in France attempt to synthesize social, cultural, and political history by situating working-class politics more broadly, either within a range of social institutions that include the workplace as well as informal and leisure organizations, or within a range of developing radical and republican political strategies, practices, and traditions. ${ }^{16}$ In such studies, many historians have 
either marginalized or ignored workers' writing practices and texts, concerned that a focus on such writing and texts might limit the scope of their analysis of politics.

Similarly, more recent studies of the transformations of labour practices and economic organization in France that have examined gender and the changing sexual division of labour have tended to avoid examining workers' writings. ${ }^{17}$ While certainly addressing significant blind spots in working-class and labour historiography and therefore broadening our understanding of nineteenth-century French society and politics, ${ }^{18}$ these more recent studies of gendered labour practices and of workers' oppositional politics have lost the value of examining workers' writings that earlier historical work had demonstrated.

This earlier labour and working-class historiography, however, implied a specific (if unstated) view of language and writing. The study of texts written by workers - like the poetry in Viollet's volume but also including broadsheets or posters, newspapers (or newspaper articles), songs, letters, and autobiographies or memoirs - tends to be removed from the context of the texts' production, particularly from the acts of writing and reading such texts, to focus instead on ideas, ideologies, mentalities, or discourses that indicate particular forms of political consciousness. ${ }^{19}$ Most labour historians do not entirely overlook the broader contexts in their study of workers' texts as discourse, situating statements from workers' texts within an analysis of a particular political movement (such as early forms of socialism and communism), a specific group of workers (often defined by trade or industry), or even an individual worker's experience. ${ }^{20}$ But regardless of how specific such analyses are they tend to treat the texts themselves and the practices that produce such texts rather unproblematically. Not only has such treatment limited our understanding of these texts, but it has also limited the examination of the relationships among workers' acts of writing (and reading), social relations, and politics.

\section{Methodological and Theoretical Issues: Working-Class Writing and Literacy Studies}

If, however, we approach workers' texts as the products of specific writing practices, we can develop a more dynamic analysis of the ways that acts of writing inscribed, reinforced, and revised social relations, social institutions, and forms of authority, domination, and resistance in industrializing, capitalist societies, such as early nineteenth-century France. ${ }^{21}$ Specifically, by examining texts as the products of particular literacy practices - acts of writing and reading — we can more precisely analyze the relationships between writing and power. In their acts of writing and reading, workingclass writers placed themselves in specific social relationships with readers and other writers - either symmetrical relationships of relative equality or asymmetrical relationships of relative inequality. Through the inscription of symbolic language, working-class writers also produced and reinforced forms of symbolic authority and domination; similarly, such forms of authority and domination were sometimes challenged through writing or reading, producing acts of resistance. ${ }^{22}$ Thus, specific acts of writing and reading were themselves forms of social and political action; they were not merely the reflection of thought that motivated political action. ${ }^{23}$ 
Taking this approach to writing and politics as its starting point, this essay is an argument for reexamining working-class literature, i.e. texts written by workers, in dialogue with what may be loosely called the "new literacy studies." ${ }^{24}$ These approaches to the study of literacy emerged from two particular movements in the late twentieth century. The first movement, known as either critical literacy or critical pedagogy, originated in late 1960s and 1970s with the work of Paulo Freire and was expanded substantially in the 1980s and 1990s. Critical literacy studies were worked out by scholars, teachers, and activists whose primary concerns were with the connections among new educational movements (e.g. mass literacy campaigns in the developing world and school reform in the United States and Canada), specific pedagogical practices, and politics. ${ }^{25}$ The second scholarly movement had roots in these critical approaches to literacy and their central concerns, but arose within the social sciences during the 1980s and 1990s and has become the dominant approach to literacy within anthropology. ${ }^{26}$ These social scientists have argued that literacy needs to be conceived of as "a set of socially organized practices which make use of a symbol system and a technology for producing and disseminating it" rather than as part of a simplified literate/illiterate (or literate/oral) dichotomy. ${ }^{27}$ Such a practice-based conceptualization of literacy was a direct critique of previous social scientists' and historians' attempts to classify societies and cultures as either literate or oral, with implicit (or occasionally explicit) assumptions about the transformative effects of moving from oral to literate. ${ }^{28}$

Both strands of the new literacy studies arose as critiques of oversimplifications in the analysis of literacy — viewing literacy as "basic skills" or in opposition to illiteracy or orality. Both also share a concern for situating specific writing and reading practices within their particular social, cultural, historical, and political contexts. As such, the new literacy studies offer a specific method for examining writing practices and their connections to a wide range of social and cultural practices, all of which are produced historically. Ultimately, examining the history of working-class literature in dialogue with the history of literacy, grounded in the approaches of the new literacy studies, yields several significant benefits. First, this dialogue allows us to present a specific critique of the formulation that literacy is simply a set of basic skills, primarily reading skills, and instead to argue that literacy includes widely varied writing and reading practices, learned and enacted throughout one's lifetime and in historically-specific social contexts. In other words, we can recover the concept of literacy from the conservative, basic skills and/or "functional" model that has emerged with particular force since the 1980s. This recovery of the concept of literacy directly engages the history of literacy with processes of educational reform that are relevant for a wide array of educational sites and institutions, including local adult-education organizations, primary and secondary schools, and even universities. ${ }^{29}$

A second benefit of adopting the methods and conceptual frameworks from the new literacy studies is that these approaches broaden the definition of writing, as well as problematize the relationships between written texts and the acts of writing. No longer assuming that writing is solely the purview of those who aspire or attain status as "writers" or even of students who are learning "writing," the new literacy studies include analyses of everyday writing practices, such as letter writing, list making, journal writing, 
sermon writing, song writing, and many others. ${ }^{30}$ In examining so-called non-traditional, alternative, or vernacular forms and practices of writing, the new literacy studies provide critical perspectives on what are valid or traditional forms, genres, and practices of writing. Such critical perspectives can help to de-naturalize commonly held conceptions of writing, much in the same way that the new literacy studies directly critique simplified conceptions of the process of being or becoming "literate" as overcoming "illiteracy." Instead, the new literacy studies encourage us to examine all forms and practices of writing that create the plethora of written texts in a given society, looking at those texts as the products of particular, socially-situated actions.

A third benefit of the new literacy studies is that it can help focus our attention on specific processes of writing and examine the materiality of those processes, where materiality is defined not just in terms of physicality but in terms of embeddedness in social relations. In doing this, the materiality of writing emerges from a close attention to the historically-specific social contexts in which writing practices and written texts are produced. This analytical focus allows us to examine the cultural work of writing in the dynamic construction of social relations, collective identities, and conceptions of the self. ${ }^{31}$ In addition, it necessarily implicates the self (or selves), identities, and social relations in the construction of forms, genres, and practices of writing, emphasizing the reciprocal relationships that exist between social contexts and the production of texts. ${ }^{32}$ This reciprocity means that individuals and groups, by engaging in various writing practices, can be agents of social change and of social reproduction, and therefore the new literacy studies help us to examine the interconnections between writing practices and processes of historical change and continuity.

This essay attempts to realize these advantages of the approaches of the new literacy studies to demonstrate the significance of reconstructing the writing practices of workers in post-Revolutionary France. In doing this, I hope to recover the importance of analyzing working-class writing, specifically poetry and songs, in order to raise questions about ways this writing can help us understand the relationships among literacy, social relations, and politics in post-Revolutionary France.

\section{Writing Songs for Parisian Singing Societies in Post-Revolutionary France}

As noted above, many workers in Paris, throughout the early nineteenth century, participated in the popular singing societies collectively known as goguettes. ${ }^{33}$ There were approximately forty to fifty of such singing societies in $1820,{ }^{34}$ and they multiplied extensively between 1830 and 1848, expanding beyond the city and permeating the surrounding countryside. ${ }^{35}$ While many goguettes continued to exist into the 1850 s, the newly-proclaimed Second Empire gradually cracked down on them, ending their existence by around 1860. Most goguettes had from thirty to two hundred participants, and many workers participated in several different goguettes. In their height during the 1830 s and 1840s, there were at least as many as 400 goguettes in Paris and its environs, and the total number of participants reached upwards of 10,000. Between 1815 and 1830, many Parisian goguettes drew their members primarily from workers in a single trade or industry, although some had a membership of workers from multiple trades. ${ }^{36}$ In 1821 , 
members of the goguettes known as Amis de la constance (Friends of Constancy) and les Admirateurs de la valeur français (Admirers of French Merit) were primarily jewelers, ${ }^{37}$ while in 1827 l'Anacréon (Anacreon) was made up "of 50 to 60 members ... almost all tinsmith workers" and la petite Goguette (The Little Goguette) was populated solely by typesetters. $^{38}$

In general, goguettes were fairly simple organizations. Most met one evening per week at a particular location, usually in a room at a wine seller's shop where participants would drink wine and sing songs throughout the evening. Most participants in goguettes were men, although some working-class women did write and sing songs at goguette meetings, especially as the singing societies expanded in the 1830s and 1840s. At the very least, women, as well as children, appear to have been observers at many of the goguettes. Many goguettes had a handful of officers, again especially as they became more numerous during the 1830s and 1840s, who did the few organizational tasks necessary. These officers included a president, who would call the meeting of the society to order and preside over the meeting, and a secretary or master of songs, who would keep records of those who volunteered to sing on a particular night. While many goguettes had a specific group of members, almost all were open to visitors, who could also sing their songs at the meetings.

The songs sung in goguettes were written by members and visitors, as well as by popular songwriters. The most revered and frequently imitated songwriter was Jean-Pierre de Béranger (1780-1857). ${ }^{39}$ In fact, many goguettiers wrote songs specifically to tunes used by Béranger, as well as using similar themes, to such an extent that these songs were viewed as having a particular style. ${ }^{40}$ Most songs contained approximately four to eight stanzas, usually with a repeated chorus. It is difficult to tell exactly how many different songs were sung on average at a goguette meeting, but since most meetings lasted the entire evening (approximately four to five hours), we can estimate that at least twenty songs were sung at most meetings. Thus, the production of songs by goguettiers was quite voluminous, and the published songbooks, pamphlets, and the occasional loose song sheets available today give us only a glimpse of the extent of these writing practices. ${ }^{41}$ In these published texts, songs were written as lyrics only without any musical notation, since they were written to be sung to existing tunes.

Both contemporary observations and scholarly studies have argued that workers who participated in these singing societies engaged in forms of political education and critique. Jules Vinçard, a ruler maker and frequent participant in goguettes, claimed in his memoirs that these singing societies marked "the first stage in the progression of the intelligence of the people" where one can see "the political spirit of the multitude," and, because of this, the goguettes facilitated the rapid events of the Revolution of $1830 .{ }^{42}$ More recently, Michel Ragon has argued that "the goguette ... played an important role in the proletariat's coming to consciousness as a social class." ${ }^{33}$ Ragon's claim suggests that these singing societies not only facilitated French labourers conceptualizing themselves as "workers" (not just as members of particular trades), but as a particular, subordinate class. Like other analyses of goguettes, Ragon proposes that these singing societies were places of workers' resistance to the class domination of the post-Revolutionary French social order. 
Such romantic descriptions of goguettes elide the complexity of both the forms of resistance produced by goguette song-writing and singing practices and the reproduction of authority and domination in these practices. This complexity can begin to be understood by first examining the social relations created by these singing societies, and, especially, by the practices of writing and singing songs.

Beginning with the early goguettes of the Restoration (1815-1830), goguette songwriters frequently referred to other members of the goguette as "friends" and expressed the friendship shared by all members of the singing society. Published in the same collection as the song "L'Artisan" cited at the beginning of this essay, the song "Réglement d'une société d'amis" (Rules of a society of friends), written by the goguettier named Demailly, begins by addressing his fellow goguette participants as friends: "Friends, so that in this enclosure / Peace and cheerfulness reigns /.../ Receive our orders." ${ }^{44}$ At the end of the song, Demailly gives one last rule for everyone to follow: "And let us always be friends!" Demailly framed his statements about friendship in his song with a sense of permanence and mutual equality based on good feeling. This sense of permanence and mutual equality implied that the friendship of the goguette was not a matter of individual preferences but was a characteristic of all members of the group gathered - it formed the basis for their solidarity as a group and defined the relationships among the individual members. That insistence on the mutual friendship among all participants of a goguette was echoed in another song in that same collection - Dupré's "Le Banquet des Joyeux" (The Banquet of the Joyous). In this song, Dupré described the participants at the goguette as a "Joyful troupe, kind troupe, / Friends of frank cheerfulness," and also claimed that friendship ties motivated participation in goguettes: "It's friendship that brings us to goguettes: / This, this is the banquet of the joyful." ${ }^{5}$

Songwriters' emphasis on goguettiers as friends in these early goguette songs was further developed by workers writing songs for goguettes during the 1830 s and 1840 s. M. Lérat, in his song "Le Sans-Souci" (The Care-Free) which was published in a songbook in 1834, addressed his fellow goguettiers as his "dear friends" in the chorus: "Without desire and without envy, / Dear friends, we let the time slip by." 46 In his song "La Goguette" published in 1841, Charbonnet invited members to participate in the society meeting and made it clear in the first verse that those to whom he extended the invitation were friends: "Enter, friends, into the depths of the sanctuary / Where Folly constantly lives. ${ }^{47}$ Gustave Leroy went even further than just referring to the goguette participants as friends in his song "Le Rendez-Vous" (The Meeting), writing that "friendship smiles in our songs." 48 Leroy's line articulates not only that goguette participants were linked by friendship but that friendship was reflected, and reproduced, in the writing and singing of goguette songs. Furthermore, the meanings of friendship for goguettiers were also reproduced in their song-writing practices - friendship which produced equality among goguette participants, "peace," "cheerfulness," and gathering together "without envy."

These particular meanings of friendship were a convention of many goguette songs, and in reproducing this convention in their song-writing and singing practices, goguettiers attempted to define the relationships among the members of the goguette in ways that had specific political implications. ${ }^{49}$ First, the equality implied by these ties of friendship created by writing and singing songs contrasted with the rigidly hierarchical 
social relations that existed outside the goguettes and permeated workers' daily lives. Second, the insistence on friendship based on good feelings, particularly feelings of "peace" and "cheerfulness," suggests that goguette songs, and the goguettes themselves, mitigated against countervailing tendencies in French society that created animosity among labourers, as well as feelings of isolation and the experience of work as alienation. ${ }^{50}$ Such animosity was most obvious in workers' violent fights (rixes) among themselves, usually among workers who were members of different trade-based associations (compagnonnages), but animosity also arose from increased competition for jobs and wages, due to the implementation of laissez-faire reforms. ${ }^{51}$ In addition, many Parisian labourers were fairly recent migrants to the capital and therefore their social ties to other residents were often weak. By asserting and, therefore, attempting to create relations of friendship based on equality, peace, and cheerfulness among participants in goguettes, songwriters resisted a hierarchical social order that, in most of their daily experiences, placed them in positions of subordination and exposed them to the domination and instability of early industrial capitalist labour. Doubtless, such assertions of friendship among the participants in goguettes did not always lead to actual friendships and good feelings within all goguettes, but the repeated efforts by goguettiers to address each other in these terms as the common form of address in their songs indicates that the acts of writing and singing goguette songs worked against the dominant characteristics of post-Revolutionary French society and were, therefore, acts of resistance.

Working-class songwriter' production (and reproduction) of concrete social relations among participants in singing societies were not, however, acts of resistance to all forms of social hierarchy and relationships of authority. Specifically, male labourers' songs often presented women and gender relations in ways that assumed forms of masculine authority and domination. These forms of authority and domination were not explicitly stated as such, suggesting that working-class men, and possibly working-class women who participated and/or attended the goguettes as well, (mis)recognized these forms of authority and domination as natural, a (mis)recognition that was produced and reinforced when they wrote and sang songs in goguettes. ${ }^{52}$ While this reproduction of masculine domination in goguette song writing and singing/reading might not be surprising, particularly given the history of many male-dominated radical groups throughout the modern era, it reveals a particular way that gender relations were naturalized in post-Revolutionary France. In addition, the particular means by which masculine domination was reproduced helps us to analyze the broader political impact of writing and singing/reading songs in goguette societies.

This production of symbolic authority and domination was most evident when labourers wrote songs that asserted men's right to control women's - particularly wives' - sexuality, an assertion most often expressed in songs that mention female infidelity. Most goguettiers did not, however, write entire songs explicitly on this subject. Instead, masculine control of sexuality was often integrated into seemingly unrelated songs, a practice that suggests the form of (mis)recognition discussed above. For example, "La Raison," a song by Emmanuel Christophe published in a pamphlet in 1824, was most likely written by Christophe after he had been asked to write a song based on a particular word, in this case "la raison" (reason). Such an exercise was a relatively common 
practice among goguettiers, demonstrating their creativity as songwriters through their abilities to manipulate language for the entertainment of the other participants in the goguette. In his first verse, Christophe set up the focus of his song on the word "raison," noting:

Un mot que tout le monde vante, Dont se moquent beaucoup de gens, Et dont l'acception constante Exprime toujours le bons sens; Un mot qui sert à la vieillesse Pour donner sa docte leçon; Un mot qui fait fuir la jeunesse, Mes chers amis, c'est la raison.
One word that everyone praises,

Which many people mock, And whose constant meaning

Always expresses good sense;

One word that comes with old age

To give its learned lesson;

One word that flees youth,

My good friends, this is reason. ${ }^{53}$

Christophe ends this opening verse by stating his relationship of friendship with his audience, reinforcing the friendship based on good feelings typically produced by goguette songs. After another verse, however, Christophe's play on this word takes a different turn:

Quand le besoin d'aimer, de plaire,

Exalte notre amour naissant,

Alors le coeur peut de se taire,

Il a besoin d'épanchement:

Timide, en voyant notre amante,

Nous éprouvons certain frisson,

Car, près d'une femme charmante

Est-on maître de sa raison?

Basile, dans le mariage

Croyait trouver le vrai bonheur;

Il sut que sa femme volage

Manquait très souvent à l'honneur:

Pour surprendre son infidelle

Il se fourra dans la cloison:

Que vit-il? il vit la cruelle

Avec Luc perdant la raison.
When the need to love, to please,

Excites our nascent love,

Then the heart can do little,

It needs to pour itself out:

Timid, in seeing our lover,

We experience true thrill,

Because, next to a charming woman

Are we masters of our reason?

Basile, in marriage

Thought to find true happiness;

He knew that his fickle wife

Very often lacked honor:

To surprise his unfaithful wife

He goes into the partition:

What did he see? He saw his insensitive wife

With Luke losing her mind.

In these two verses, Christophe places reason and sexuality in symbolic opposition, depicting sexuality as a force that is difficult to control. In both verses, women symbolize this uncontrollable force, as well as being "fickle" and "often lack[ing] honor." These representations of women, and Basile's wife specifically, appears to make them able to control men. Through such representations, Christophe evoked humor by presenting himself (as well as his listeners) as an outside observer, critical of Basile's inability to enact the rightful role of any husband by controlling his wife. Thus while the representation of women as unrestrained sexuality might appear to invert women's subordination and place them in control of male reason, the humor of this situation reinforced a (mis)recognition of male authority and control as natural. The naturalization of this form of authority and control was further reproduced by the rest of the song, which continued in a different direction, closing with: 

Sur ce mot s'il fallait m'étendre Je ne finirais pas, je crois;
On this word I need to dwell
I'm not yet finished, I think;
Pourtant, lorsqu' on veut bien s'entendre, Yet, when one wants to be heard clearly,
Il faut s'en servir quelquefois:
Dans le commerce, en politique,
En tous lieux, en toute saison,
Contre l'insolent, le critique,
Employons toujours la raison.
One needs to make use of it sometimes:
In commerce, in politics,
In all places, in all seasons,
Against the insolent, criticism,
Always use reason.

This closing verse continued to hide the suggestion provoked by the earlier humorous presentation of sexuality - that men, using their reason, should control women, especially their wives. By not stating this explicitly, though, Christophe inscribed a naturalized relationship of power into a standard goguette song, one that produced good feelings of friendship among goguette participants, and the humorous atmosphere of the goguettes.

This practice of naturalizing male control of female sexuality through humorous songs was somewhat more common in the earlier goguette songs written between 1815 and 1830. Despite the wider diversity of songs written the 1830s and 1840s, though, many songwriters inscribed masculine authority in more subtle ways. For example, in writing a song about a particular goguette, Eugène Duhoux began by invoking the good feelings shared by participants of the goguette in the beginning chorus:
Dans le plus beau délire,
Par nos joyeux accents,
In the most beautiful folly,
Du vrai dieu de la lyre
By our joyous tones,
Montrons-nous les enfants! \} Bis.
Of the true god of the lyre
Children, let's show ourselves! \} repeat..$^{54}$

After two verses describing the goguette and inviting singers to participate, young women are specifically invited to participate in the goguette in the following verse:
Venez aussi, fillettes dégourdies,
Come also, bright little girls,
Aux frais minois, aux regards séduisants,
With fresh little faces, with seductive looks
A qui l'Amour, par ses espiègleries,
For whom Love, by its mischievousness
Fait palpiter le coeur avant seize ans.
Makes the heart beat before sixteen years.
Sexe charmant, dont l'aspect nous enchante,
Notre miroir est toujours dans tes yeux;
Viens partager notre joie enivrante:
Charming sex, whose appearance enchants us,
Nous nous croirons à la table des dieux!
Your eyes are always our mirror,
Come share our intoxicating joy:
We believe to be at the table of gods!

Even though Duhoux's song invited women to participate in the goguette, it did not invite them to be equal participants in the meeting. Instead, women were asked to "share in our [i.e. men's] intoxicating joy," rather than to help to create the good feelings that were an essential part of the social interaction at goguette meetings. Duhoux's invitation for women's participation in the goguette, then, was extended from a position of (male) authority and placed women in a position of subordination. In addition, Duhoux represented women as the "charming sex" "with seductive looks" and "whose appearance enchants" men, a representation of women as objects of/for men's pleasure. As in 
Christophe's song, Duhoux did not dwell on this gender dynamic but rather continued with other related themes and again reinforced the good feelings among participants in the goguette:

De nos auteurs joyeuse pépinière, Dont le talent brille de jour en jour, Sans oublier la Lice chansonnière, Viens embellir souvent notre séjour. Venez, amis, sous notre humble coupole, Au nom chéri d'Émile qui n'est plus: De la chanson, à votre douce école, Nous deviendrons des émules de plus. Dans le plus beau délire, etc.

Gais visiteurs, qui de la chansonnette Fûtes toujours les zélés partisans, Du dieu des arts, en célébrant la fête, Nous conservons l'égalité des rangs. Restons unis, bannissons la licence, Souvent nuisible à la franche gaîté: Buvons ensemble au soutien de la France, Sur les autels de la Fraternité!
From our joyous nursery of authors, Whose talent shines from day to day, Without forgetting the Lice Chansonnière, Come often to beautify our rest.

Come, friends, under our humble Cupola, In the dear name of Émile who is no longer: From song, to your sweet school, We will become rivals again. In the most beautiful folly, etc.

Happy visitors, who from little songs Always become zealous partisans, From the god of art, celebrating the party, We maintain the equality of ranks. Let us stay united, banish decadence Often detrimental to true happiness: Let's drink together to the support of France, To the honors of Fraternity!

By ending his song with such calls for unity, happiness, fraternity, and maintaining "the equality of ranks," Duhoux reinforced the social relations that created the solidarity of the goguette and therefore resisted the hierarchical, alienating social order. But this solidarity was based on a tacit (mis)recognition of masculine authority as natural, which was itself inscribed by Duhoux in his song. Duhoux's call for maintaining "the equality of ranks" might have sought to overcome divisions and hierarchy among male workers, but it did not eliminate the gender hierarchy and working-class women's subordinate position within that hierarchy.

This reproduction of a gendered hierarchy in goguette songs dovetailed with articles that appeared in the oppositional working-class press, which by the late 1840 s also advocated other forms of male authority. In particular, the newspapers L'Atelier and La Ruche Populaire argued that working-class men were (and should be) the primary wage earners in working-class families, while working women were (and should remain) economically dependent on their husbands. ${ }^{55}$ This argument was part of a strategy to advocate for higher wages for working-class men - a type of "family wage" argument — and, at the same time, to ensure women's place in the family and the workshop remained subordinated to men's. ${ }^{56}$ Thus, while working-class men were both caught up in and resisted relations of domination and subordination that developed out of early forms of industrialization and the laissez-faire social order in postRevolutionary France, they also engaged in acts of authority over and domination of working-class women.

These forms of political action were not the sort of politics that contemporary observers and scholars have lauded these singing societies for teaching to workers. Even the ways that goguette songs created relationships of friendship and good feelings among 
participants that resisted the dominant social order were not the forms of resistance that many have claimed were created by the goguettes. Particularly between 1815 and 1830, these singing societies were constantly under surveillance by the police who were concerned about the singing of seditious and overtly political songs — namely, songs that criticized the king and referred positively to the Revolution or Napoleon. ${ }^{57}$ Some goguettes moved locations to avoid being shut down by the police, and people who were observed singing, writing, or possessing songs that openly criticized the king were occasionally imprisoned. The struggle of many goguettes for their very existence was, therefore, an act of resistance against the restored Bourbon monarchy and the Parisian police. In addition, by the mid-1830s and into the 1840 s, some workers wrote songs for goguettes that articulated a militant worker identity and presented a more overt critique of the injustice of the laissez-faire social order.

One of the best examples of this practice is the song "Ouvriers, Associez-Vous!" (“Associate, Workers!”), written by E. Garnier and published in $1841 .{ }^{58}$ In this song, Garnier developed the rhetoric of workers' association in order to demand that workers act in response to the unjust social order. ${ }^{59}$ Garnier closed his song:
A l'oeuvre donc, vrais enfants de la France;
De votre mère écoutez tous la voix.
To work then, true children of France;
Everyone listen to the voice of your mother(land).
Par vos labeurs, prouvez à l'ignorance
Que l'oisif seul est le fléau des lois.
By your labors, prove to ignorance
Que par vos mains notre avenir se fonde.
Courage! amis, le ciel luira pour tous.
That only the idle is the scourge of laws.
That our future is founded by your hands.
Courage! Friends, heaven will shine for all.
A nos enfants léguons un meilleur monde:
Ouvriers, associons-nous!
Let us leave our children a better world:
Workers, let us associate!

All earlier verses of this song end with the phrase "Workers, associate yourselves!" or more loosely translated "Workers, unite in association!" (“Ouvriers, associez-vous!") — the title of the song — but Garnier changed this last verse to include himself in the group of workers his song addresses by stating "Workers, let us associate!" ("Ouvriers, associons-nous!") Clearly including himself in this call for working-class solidarity, Garnier also criticized "the idle," drawing on a common class distinction between workers and the idle rich.

Like the final verse of Garnier's song, the song "Aux Coeurs de Roche" ("To the Hard-Hearted"), written by Eléonore Lelarge, condemned the rich by discussing their treatment of the working poor. ${ }^{60}$ Lelarge's critique was, however, couched in much stronger terms, as seen in the first and last verses:

Riches et puissans de la terre,

Qui n'avez point connu la faim,

Vous qui riez de la misère,

Dansez, quand le peuple est sans pain.

Les balles et les folles soirées Bis.

Sont, pour vos épouses, vertus, Bis.

Souvent par d'autres adorées:

Dansez, ça vous vaut des écus. \} Bis.
Rich and powerful of the earth,

Who have never known hunger,

You who laugh at poverty,

Dance, when the people are without bread.

Balls and mad parties

Are, for your wives, virtues,

Often adored by others:

Dance, this is worth some crowns to you. 
Déshonorez le prolétaire.....

S'il vous en demande raison,

On punira ce téméraire

Par deux ou trois ans de prison.

Tremblez, le peuple enfin s'éveille,

D'un mot, il peut, dans sa fureur,

Broyez ces maîtres de la veille!

Fuyez!... Je crains pour vous malheur!
Dishonor the proletarian.....

If he demands satisfaction from you,

This recklessness will be punished,

By two or three years in prison.

Tremble, the people finally wake up,

In a word, they can, in their furor,

Crush these masters of yesterday!

Flee!... I fear misfortune for you!

Lelarge's song presented a scathing critique of the "rich and powerful" and also forecast their (possibly violent) downfall at the hands of "the proletarian." In addition, lives of "the people" and "the proletarian" were presented in stark terms - they suffered from "lack of bread," "poverty," and imprisonment for fighting ("[demanding] satisfaction”). As did Garnier's song, therefore, Lelarge presented possible responses for workers to their common situation, as well as a particularly militant critique of the dire consequences of early industrial capitalism and the laissez-faire social order for all French workers. $^{61}$

This critique of early industrial capitalism written into certain songs and the struggles of goguettes against the police were the forms of resistance engaged in by the workingclass members of these singing societies that were most apparent to observers. That does not mean, however, these were necessarily the most significant or most representative forms of political action produced by writing and singing songs at goguette meetings. As we have seen, these literacy practices formed and reproduced the social relationships among participants in these singing societies - acts that defined the meanings of these social institutions and its writing practices. While writing and singing songs defined the relationships among male participants by equality and good feelings, resisting the hierarchy and domination of the laissez-faire social order, these literacy practices also produced symbolic forms of masculine authority and domination - placing working-class women in positions of subordination. Because of the complexity of the connections among gender, class, and early industrial capitalism in nineteenth-century France, these songs written for the Parisian goguettes demonstrate that it is insufficient to analyze the writing practices of working-class women and men solely as acts of resistance or opposition. ${ }^{62}$ Furthermore, goguette song-writing practices suggest that we must analyze the interplay of authority, domination, and resistance in any given literacy practice in order to understand the place of working-class writing in the dynamic construction of social relations and politics.

\section{Conclusion: Orality and Literacy, Songs and Poetry}

The practices of writing and singing songs were central to these nineteenth-century Parisian singing societies, as they were the very basis of these organizations' existence. What, however, did writing songs in this case mean? Were songs composed orally at the meetings, only to be transcribed by a limited number of people and later printed in various forms? Some scholars have argued that what made songs so important to workers during this time was their connection to "folk" and "oral" traditions, even describing 
songs as an "oral medium." ${ }^{3}$ The lack of manuscript evidence that might detail the precise construction of song-writing practices certainly leaves open the possibility that only certain participants in goguettes did the physical writing of the songs, with their efforts later being published. ${ }^{64}$ Rather than simply adopt this position, though, I find this issue of evidence more instructive for raising questions about what constitutes writing, the interrelationships between the oral and the written, and why we might be quick to dismiss the possibility of the actual act of writing when a form of expression is "close" to an "oral" tradition. The few images we have representing goguette participants usually show them drinking, smoking, and singing from or holding pieces of paper, presumably containing the songs that they wrote. ${ }^{65}$ Such images, combined with the large number of published song collections, pamphlets, and individual song sheets attributed to many different songwriters certainly do not constitute infallible evidence that all, or most, participants in goguettes actually physically wrote their songs prior to singing them and then read from their written manuscripts while singing. ${ }^{66}$

So, analyzing goguette songs as the products of specific literacy practices raises just as many questions as the potential insights it gives, given the paucity of specific evidence as to when, where, and whom the physical acts of writing involved. Should we see the writing of such songs as the products of individual writers or of a group, and what does this suggest for how we understand literacy? How do we understand the interplay of oral speech/song and the acts of writing? Such questions emerge with particular force in analyzing goguette songs as literacy practices and not just as evidence of working-class discourse or ideologies.

While other forms of writing in which members of the French working class engaged at this time do not help to answer these questions, they do help show that particular acts of writing were far from foreign to many members of this group. As with their practices of writing songs for goguettes, French workers constructed, reproduced, and resisted particular social relations and the wider social order by writing letters. Some workers even wrote letters to well-known writers such as George Sand and Eugène Sue. These letters to famous writers often were motivated by or contained requests for material aid, detailing workers' experiences of poverty, unemployment, and debt, and, as such, these letters can be seen as a form of resistance. These forms of resistance through written charitable appeals, regardless of the exact nature of the charitable relationships, hardly seem modern or what we might consider typical working-class oppositional politics. We should not, however, assume these were merely archaic acts that somehow made their way into workers' writing practices. ${ }^{67}$ In fact, these acts of writing letters to elicit material support from famous writers were based on a shared critique of the social order among these writers and their working-class interlocutors. Thus, these letter-writing practices were more modern than might be initially apparent — part of a developing criticism of early industrial capitalism, the laissez-faire social order, and working-class poverty that emerged in the nineteenth century. This form of criticism might appear quite different from the forms of collective action taken by workers in their conflicts with their masters, an issue that might be best addressed by examining the individualism in charitable appeals and its implications for understanding the constitution of the self. 
A similar argument holds for the writing and singing/reading of songs for Parisian working-class singing societies. While these writing practices bear some resemblance to earlier practices of carnival or charivari in their frequently jovial and joking style, they also inscribed a peculiarly modern set of social relations among members of these singing societies. ${ }^{68}$ As ties of friendship defined by good feelings and equality, these social relations resisted the conflict and competition among workers in the post-Revolutionary social order. In addition, workers' acts of writing and singing songs in goguettes inscribed symbolic forms of masculine authority and domination. These forms of masculine domination cannot be interpreted merely as the persistence of patriarchy but must be seen within the context of the goguettes themselves - sites of working-class solidarity in response to the social dislocation caused by laissez-faire labour reforms and the domination of the early industrial capitalist labour. Masculine domination inscribed in workers' songs, and in some of their letters to famous writers, was very much part and parcel of the development of a modern social order and in modern practices of working-class resistance. Ultimately, these song-writing practices were at once innovative, responding and resisting one facet of modernity (the consequences of early industrial capitalism), and traditional, preserving ideas about male solidarity that guilds, confraternities, masonic lodges, and other organizations had previously embodied, as well as notions of gender identity and authority.

French workers' writing practices in the nineteenth century reveal, therefore, multiple connections among writing, social relations, and politics. Their acts of writing and reading/singing were acts of resistance, but also acts of authority and domination. The interplay of these forms of power and acts of writing and reading demonstrates why we need a more complex understanding of workers' politics and workers' literacy practices in industrializing societies, such as nineteenth-century France. More generally, the complexity of the embeddedness of these writing and reading practices in specific social contexts, in processes of historical change, and in relations of power suggests that scholars analyzing literature and literacy should carefully consider the realm of the political, as well as the social and historical, in their analyses of particular forms of writing and reading. As stated above, a comparative, historical analysis of different forms, genres and practices of writing depends upon precise study of each particular form, genre, and practice and their relationships to historically-specific social and political contexts. And we need to examine non-traditional, alternative, and vernacular forms, genres, and practices of writing, in order for a comparative analysis of the history of writing to detail sufficiently the place of writing within the range of a society's literacy practices. This kind of comparative analysis can, in the end, lead to more precise, nuanced understandings of the workings of literacy, giving us critical perspectives on contemporary debates over literacy and educational reforms, the place of writing and reading within those debates, the relationships between literacy and forms of social organization (such as forms of capitalism), and our own pedagogical practices. 


\section{Notes}

1 F. Dauphin, "L'Artisan," in Le Nouvel Enfant de la Goguette, ed. Emile Debraux (Paris: Le Couvey, 1823), 172. All translations of songs from French to English in this essay are my own. I have not attempted to reproduce the artistry of the original French, merely to give the reader a sense of the meaning in English.

2 Eugène Baillet, "Préface ou Extraits de l'Histoire de la Goguette," in Chansons et Petits Poèmes (Paris: L. Labbé, 1885), xx.

3 Alphonse Viollet, Les Poètes du peuple au XIX'e siècle (Genève: Slatkine, 1980; facsimile reproduction, Paris: libr. française et étrangère, 1846).

4 Ibid., iv.

5 Charles Poncy, Le Chantier, poésies nouvelles, préface de George Sand (Paris: Perrotin, 1844); Charles Poncy, Le Marine (Paris: Lavigne, 1842); and Magu, Poésies de Magu, tisserand à Lizy-sur-Ourcq (Paris: Delloye, 1839).

6 Jérôme-Pierre Gilland, Les Conteurs ouvriers, dédiés aux enfants de la classe laborieuse, préface de George Sand (Paris, 1849). Sand also had extensive correspondence with Magu, Gilland, as well as with the carpenter and compagnon Agricol Perdiguier, and their families. Their letters are saved in Sand's papers in the Bibliothèque Nationale de France, Manuscrits Occidentales, Papiers George (Aurore) Sand, n.a.f. 24811, and analyzed in Steven Edward Rowe, "Literacy Practices of the Laboring Poor in France, 1800-1860" (Ph.D. diss., Duke University, 2002).

7 For example, see E. P. Thompson, The Making of the English Working Class (New York: Vintage Books, 1966); Robert J. Bezucha, The Lyon Uprising of 1834: Social and Political Conflict in the Early July Monarchy (Cambridge: Harvard University Press, 1974); Ronald Aminzade, Class, Politics, and Early Industrial Capitalism: A Study of Mid-Nineteenth Century Toulouse, France (Albany: SUNY Press, 1981); Donald Reid, The Miners of Decazeville: A Genealogy of Deindustrialization (Cambridge: Harvard University Press, 1985); Michael P. Hanagan, Nascent Proletarians: Class Formation in Post-Revolutionary France (Cambridge, MA: Basil Blackwell, 1989); William H. Sewell, Jr., Work and Revolution in France: The Language of Labor from the Old Regime to 1848 (New York: Cambridge University Press, 1980); and Jacques Rancière, The Nights of Labor: The Workers' Dream in Nineteenth-Century France, trans. John Drury (Philadelphia: Temple University Press, 1989).

8 Thompson, Making of the English Working Class, 234. All of the studies cited above for France also discuss the persistence of artisans as the core labour force in industrial production throughout most of the nineteenth century.

9 See, for example, Bezucha, The Lyon Uprising of 1834 on the Lyon silk workers' revolts; and Sewell, Work and Revolution on 1848; as well as Iorwerth J. Prothero, Radical Artisans in England and France, 1830-1870 (Cambridge, UK: Cambridge University Press, 1997).

10 Jacques Rancière, "The Myth of the Artisan: Critical Reflections on a Category of Social History," International Labor and Working Class History 24 (1983): 3. More specifically, Rancière argues that the organization of specific trades is not the best way to understand workers in early industrial France as a group, defining proletarians by the "aleatory character of a situation daily put into question." Rancière, Nights of Labor, xxxiii.

11 In Work and Wages: Natural Law, Politics and the Eighteenth-Century French Trades (New York: Cambridge University Press, 1989), Michael Sonenscher has raised some questions as to what extent these labour practices were new to nineteenth-century industrial production, arguing that many of these practices were widespread in eighteenth-century France. More recently, Leora Auslander has raised some questions about Sonenscher's critique in her work on furniture making, Taste and Power: Furnishing Modern France (Berkeley: University of California Press, 1996).

12 See Sewell, Work and Revolution. 
13 These three arguments are advanced in Thompson, Making of the English Working Class; Sewell, Work and Revolution; Rancière, The Nights of Labor; and William M. Reddy, Money and Liberty in Modern Europe: A Critique of Historical Understanding (New York: Cambridge University Press, 1987), 154-96.

14 See Edgar Leon Newman, "The Blouse and Frock Coat: The Alliance of the Common People of Paris with the Liberal Leadership and the Middle Class During the Last Years of the Bourbon Restoration," The Journal of Modern History 46 (1974): 26-59 and Edward Berenson, Populist Religion and Left-Wing Politics in France, 1830-1852 (Princeton: Princeton University Press, 1984).

15 Prothero, Radical Artisans, presents a comparative study of artisan radicalism in England and France, with an examination of a wide array of social institutions and their practices and politics, making the complexity of workers' politics in the nineteenth century particularly evident.

16 In addition to Prothero, Radical Artisans, other examples include Jill Harsin, Barricades: The War of the Streets in Revolutionary Paris, 1830-1848 (New York: Palgrave, 2002) and W. Scott Haine, The World of the Paris Café: Sociability among the French Working Class, 1789-1914 (Baltimore: The Johns Hopkins University Press, 1996).

17 For example, see Juddith Coffin, The Politics of Women's Work: The Paris Garment Trades 1750-1914 (Princeton: Princeton University Press, 1996); Tessie Liu, The Weaver's Knot: The Contradictions of Class Struggle and Family Solidarity in Western France, 1750-1914 (Ithaca: Cornell University Press, 1994); Elinor Accampo, Industrialization, Family Life, and Class Relations: Saint-Chamond, 1815-1914 (Berkeley: University of California Press, 1989); and Gay Gullickson, Spinners and Weavers of Auffay: Rural Industry and the Sexual Division of Labor in a French Village, 1750-1850 (Cambridge: Harvard University Press, 1986).

18 As Joan Scott, among others, has observed, the identity of "worker" in nineteenth-century France was coded as masculine, while l'ouvrière (working woman) was a repugnant word. See Joan Wallach Scott, Gender and the Politics of History (New York: Columbia University Press, 1988), 139-163. Scott, in particular, has called for using gender as an analytical category, and not just as a synonym for women, to examine all historical processes. In order to understand the dynamics of power in nineteenth-century French society, and therefore to fully understand workers' politics and social relations, one certainly has to heed Scott's call. After all, at the beginning of the nineteenth century, the Napoleonic Code inscribed women's subordination and men's domination into national law: women were declared legal non-persons (the same as minors); the divorce law limited grounds for divorce to degrading criminal sentences, adultery, and physical abuse (in addition to divorce by mutual consent); married women were denied property rights; Article 213 of the Code required married women to obey their husbands; and the husband's rights over his wife (puissance maritale) included the right to kill her and her lover if the husband discovered them engaged in sexual activity. In practice, husbands freely engaged in violence against their wives, often in ways that were legally condoned but occasionally challenged in open court by women seeking marital separation. For elite men, such violence was justified in court through references to a code of honour, and, for working-class men, violence was argued in court as an appropriate way of disciplining one's wife. See William M. Reddy, The Invisible Code: Honor and Sentiment in Postrevolutionary France (Berkeley: University of California Press, 1998), 65-114.

19 Sewell makes his case for the use of the concept of discourse since "the coherence of the thought lies not in particular texts or in the 'work' of particular authors, but in the entire ideological discourse constituted by a large number of individually fragmentary and incomplete statements, gestures, images, and actions." Sewell, Work and Revolution, 9. In his article on worker poets in the 1830s and 1840s in France, Edgar Leon Newman makes it clear that the issue he explores is the "working-class mentality" and "what (workers) 
thought." Newman, "L'arme du siècle, c'est la plume: The French Worker Poets of the July Monarchy and the Spirit of Revolution and Reform," The Journal of Modern History 51 (1979): D1204, D1211, D1219.

20 In their discussion of workers' writing, Sewell and Prothero focus on the contexts of particular trades, trade-based associations, and political movements, and Rancière contextualizes workers' texts even more specifically, examining individual life experiences as well as particular forms of labour and working-class organizations. His precise contextualization is, in fact, part of Rancière's critique of French historians' argument about workers' political militancy: he argues that one should carefully examine each text and its writer's (or writers') particular place in French society, especially in relation to other workers.

21 This form of analysis can, I hope, begin to address William Sewell's concerns about the need to take both social and cultural structures seriously, while accounting for human action and examining historical transformations. See William H. Sewell, Jr., Logics of History: Social Theory and Social Transformation (Chicago: University of Chicago Press, 2005).

22 My emphasis on both producing/reinforcing power and well as resisting it through one's literacy practices is an attempt to address the critique presented by Lila Abu-Lughod in "The Romance of Resistance: Tracing Transformations of Power through Bedouin Women," American Ethnologist 17 (1990): 41-55. In addition, I make use of Pierre Bourdieu's extensive analysis of symbolic authority and domination in Language and Symbolic Power, trans. Gino Raymond and Matthew Adamson (Cambridge: Harvard University Press, 1991). Finally, the recent work of the "new working-class studies" also seeks to avoid romanticizing and oversimplifying resistance, as represented in John Russo and Sherry Lee Linkon, eds., New Working-Class Studies (Ithaca: ILR Press, 2005).

23 This somewhat fine distinction certainly depends upon the particular writing practice in question. One can conceive of literacy practices carried out solely for reflection, but such practices (diaries, notes, etc.) would be those whose audience is limited to the individual writer her/himself. For a more complex analysis of the link between practice and thought, see the work of Pierre Bourdieu and his theory of the habitus, which he initially developed in Outline of a Theory of Practice, trans. Richard Nice (New York: Cambridge University Press, 1977).

24 While this essay is focused on working-class literature, one can extend the approaches of the new literacy studies to think about the history of literature more broadly conceived. Such a project is similar to the call that made in Margaret W. Ferguson, Dido's Daughters: Literacy, Gender, and Empire in Early Modern England and France (Chicago: University of Chicago Press, 2003). Ferguson's concern with examining texts written by early modern women as social and political processes of different literacies parallels many of the concerns in this essay. In addition, Ferguson's insightful analysis into the meaning of the concept of literacy and into debates about this concept present an important, broader prism through which the new literacy studies discussed here should be viewed. A central part of this broader view of literacy is Ferguson's explicit engagement with the work of literary scholars and conceptions of literature, foregrounded in her theoretical discussions on pages 31-61.

25 See Paulo Freire, Pedagogy of the Oppressed, trans. Myra Bergan Ramos (New York: Continuum, 1990 [1970]); Peter McLaren, Life in Schools: An Introduction to Critical Pedagogy in the Foundations of Education, $3^{\text {rd }}$ Ed. (New York: Longman, 1998); Donaldo P. Macedo, Literacies of Power: What Americans are not Allowed to Know (Boulder, CO: Westview Press, 1994); Henry Giroux, Teachers as Intellectuals: Toward a Critical Pedagogy of Learning (Granby, MA: Bergin \& Garvey, 1988); and Colin Lankshear and Peter McLaren, eds., Critical Literacy: Politics, Praxis, and the Postmodern (Albany: SUNY Press, 1993). 
26 See Shirley Brice Heath, Ways with Words: Language, Life, and Work in Communities and Classrooms (New York: Cambridge University Press, 1983); Sylvia Scribner and Michael Cole, The Psychology of Literacy (Cambridge: Harvard University Press, 1981); Brian V. Street, Literacy in Theory and Practice (New York: Cambridge University Press, 1984); "Introduction: The New Literacy Studies," in Cross-Cultural Approaches to Literacy, ed. Brian V. Street (New York: Cambridge University Press, 1993), pp. 1-22; and Niko Besnier, Literacy, Emotion, and Authority: Reading and Writing on a Polynesian Atoll (New York: Cambridge University Press, 1995).

27 Scribner and Cole, Psychology of Literacy, 236.

28 Most histories of literacy rely on the dichotomous conception of literacy (usually literate/oral, often as the change from orality to literacy) that is being criticized here, including the seminal study of literacy in France, François Furet and Jacques Ozouf, Lire et Écrire: L'Alphabétisation des Français de Calvin à Jules Ferry, 2 vols. (Paris: Les Editions de Minuit, 1977). Even more recent histories of literacy, such as David Vincent, Literacy and Popular Culture, England 1750-1914 (Cambridge: Cambridge University Press, 1989), tend to rely on conceptualizing and defining literacy in dichotomous terms and see literacy primarily as a (neutral) set of skills, often measuring the change from orality to literacy by looking at signatures on marriage documents and looking at specific acts of reading and writing as post-literacy cultural practices.

29 See Freire, Pedagogy of the Oppressed, 101-118; Macedo, Literacies of Power, 16-35, 137 183; and Lankshear and McLaren, Critical Literacies, 217-245, 247-269.

30 Analyses of these forms of writing can be found in Heath, Ways with Words; Besnier, Literacy, Emotion, and Authority; Miriam Camitta, "Vernacular Writing: Varieties of Literacy Among Philadelphia High School Students," in Cross-Cultural Approaches to Literacy, ed. Brian V. Street (New York: Cambridge University Press, 1993), 228-246; and Amy Shuman, "Collaborative Writing: Appropriating Power or Reproducing Authority?" in Cross-Cultural Approaches to Literacy, ed. Brian V. Street (New York: Cambridge University Press, 1993), 247-271.

31 James Paul Gee, "The New Literacy Studies: From 'Socially Situated' to the Work of the Social," in Situated Literacies: Reading and Writing in Context, ed. David Barton, Mary Hamilton, and Roz Ivanic (London: Routledge, 2000), 190-191.

32 For an analysis of the relationships between literacy and the self, see Steven E. Rowe, "Writing Modern Selves: Literacy and the French Working Class in the Early Nineteenth Century," Journal of Social History 40:1 (Fall 2006): 55-83.

33 In comparing goguettes with counterparts in England, Prothero, Radical Artisans, translates "goguette" as a "free and easy" singing society (292-296). Similar song-writing clubs existed in at least some provincial manufacturing towns in France as well. William Reddy provides an analysis of song-writing practices by participants in singing societies in Lille during the Second Empire in The Rise of Market Culture: The Textile Trade and French Society, 1750-1900 (New York: Cambridge University Press, 1984), 253-288. Axel Körner, Das Lied von einer anderen Welt: Kulturelle Praxis im französischen und deutschen Arbeitermilieu, 1840-1890 (Frankfurt: Campus, 1997) is an interesting study comparing goguette song writing with German workers' song writing in the mid-nineteenth century.

34 Archives Nationales, Paris, France (hereafter AN), F7 6700, Dossier 28, Rapport sur les Sociétés Lyrico-Bachique (31 mars 1820).

35 Robert Balland, "Les Goguettes Rurales autour de Paris au Milieu du XIX Siècle," Ethnologie Française 12 (1982): 247-60.

36 Several police surveillance reports of goguettes (located in AN, $\mathrm{F}^{7}$ 6700, Dossier 28, Dossier concernant les SOCIÉTÉS CHANTANTES, DITE GOGUETTES, établies à Paris ou aux environs: 1816-1828), simply describe the participants as "ouvriers" (workers), presumably because the agents could not tell what trade(s) the participants worked in, saw those distinctions as unimportant, and/or the participants represented many different trades. 
37 AN, F7 6700, Dossier 28, Rapport du 24 août 1821.

38 AN, F7 6700, Dossier 28, Rapport de la Préfecture de Police de Août 1827.

39 Béranger's name indicates that his family had some pretensions to nobility, but his social class is probably best described as petit bourgeois. Béranger's grandfather was a tailor, his father was a notary in the provinces and then a bookkeeper in Paris, and his mother worked for a grocer. Béranger himself worked as a typographer, a minor banker, and in a lending library — vacillating between working-class and bourgeois status.

40 This imitation of Béranger's songs is one reason why Jacques Rancière argues that goguette songs were not the products of an autonomous working-class culture but were a sort of intermediary cultural phenomenon - a form of popular culture with ties to the working class and to a dominant culture. See Jacques Rancière, "Ronds de fumée (Les poètes ouvriers dans la France de Louis-Philippe)," Revue des Sciences Humaines LXI, no. 190 (1983), 35-36, and "Good Times or Pleasure at the Barriers," in Voices of the People, ed. Adrian Rifkin and Roger Thomas (New York: Routlege, 1988), 49-51. This argument about songs written for the goguettes, though, is part of his larger argument about working-class writing, most fully developed in The Nights of Labor.

41 Throughout the remainder of this essay, I will refer to participants in goguettes as goguettiers, for lack of an appropriate translation of this French word.

42 Vinçard (aîné), Mémoires épisodique d’un vieux chansonnier saint-simonien (Paris: E. Dentu, 1878), 24-27. The Revolution of 1830 in France was over almost as soon as it started, with the Bourbon monarchy and the absolutist reign of Charles X ending without any significant fight during the month of July 1830, giving it the name the "July Revolution."

43 Michel Ragon, "Introduction," in Les Poètes du peuple au XIXe siècle, ed. Alphonse Viollet (Paris: libr. française et étrangère, 1846; facsimile reprint, ed. Michel Ragon, Geneva: Slatkine, 1980), ii-iii.

44 Demailly, "Réglement d'une société d'amis," in Le Nouvel Enfant de la Goguette, ed. Emile Debraux (Paris: Le Couvey, 1823), 198-201.

45 Dupré, "Le Banquet des Joyeux," in Le Nouvel Enfant, 83-85.

46 M. Lérat, "Le Sans-Souci," in La Goguette, chansonnier de table et de société (Paris: Les marchands de nouveautés, 1834), 244-245.

47 Charbonnet, "La Goguette," in La Goguette, Receuil de Toutes les Bonnes Chansons des Sociétés Chantantes; Publiée par Guillaume et Benard, ouvriers typographes (Paris: Guillaume et Benard, 1841), 129-30.

48 Gustave Leroy, "Le Rendez-Vous," in La Voix du Peuple! Oeuvres Complètes de Chansons Populaires, de Gustave Leroy (Paris: Eyssautier, 1844), 21-22.

49 In analyzing the conventions of the goguette songs here, I am arguing that these conventions had particular meanings and reveal the politics of why such a convention existed and was continually reproduced in song-writing and singing practices. In doing this, I draw indirectly on Pierre Bourdieu's discussion of orthodoxy and heterodoxy from Outline of a Theory of Practice, 168-171.

50 I use the concept of alienation here following Rancière's arguments about the experience of labour for large numbers of workers in Paris in the early nineteenth century. See Rancière, The Nights of Labor, 58, 67, 211. In his analysis of work as alienation, Rancière draws on Marx's concept of alienating (or estranged) labour in capitalist society, particularly as "manifested not only in the result but in the act of production - within the producing activity itself." See Karl Marx, "Economic and Philosophic Manuscripts of 1844," in The Marx-Engels Reader, ed. Robert C. Tucker (New York: Norton, 1978), 73.

51 There are some parallels here between goguettiers insistence on good feelings in their songs and other workers' uses of farce in songs. See Reddy, Rise of Market Culture, 280.

52 Pierre Bourdieu calls this form of authority and domination doxa, in his theory of symbolic power. See Bourdieu, Outline of a Theory of Practice, 159-71 and Bourdieu, Language and Symbolic Power, 163-70. 
53 Emmanuel Christophe, "La Raison," in L'Ami de la goguette, chansons par G.-J.-E. Christophe (Paris: impr. de A. Bobée, 1824), 39-41.

54 Eugène Duhoux, "Les Enfants de la Lyre," in La Goguette, Receuil de Toutes les Bonnes Chansons des Sociétés Chantantes, 325-327.

55 Victoria E. Thompson, The Virtuous Marketplace: Women and Men, Money and Politics in Paris, 1830-1870 (Baltimore: Johns Hopkins University Press, 2000), 62-72.

56 Victoria Thompson does point out that this position was not universal among workingclass radicals, as Saint-Simonian feminists advocated a society where both women and men were free from material concerns. See Louise Tilly and Joan W. Scott, Women, Work, and Family (New York: Routledge, 1989) and Accampo, Industrialization, Family Life, and Class Relations for further discussions of the conception of a "family wage" and how working-class family economies changed in nineteenth-century France.

57 Pierre Brochon claims that "the least we can say is that all of the goguettes appear to have been a battlefield between the democratic opposition and the police." See Brochon, Le Chanson Française (I): Béranger et son Temps (Paris: Editions sociales, 1956), 17. The extent of police surveillance during the Restoration is evident in the archival records, which have been collected into one dossier in the Archives Nationales in Paris (AN, F ${ }^{7}$ 6700, Dossier 28, Dossier concernant les SOCIÉTÉS CHANTANTES, DITE GOGUETTES).

58 E. Garnier, "Ouvriers, Associez-Vous!" in La Goguette, Receuil de Toutes les Bonnes Chansons des Sociétés Chantantes, 22-24.

59 The language of association, as form of class solidarity, is analyzed thoroughly by Sewell and also discussed some by Rancière, Prothero, and Price.

60 Eléonore Lelarge, "Aux Coeurs de Roche," in La Goguette, Receuil de Toutes les Bonnes Chansons des Sociétés Chantantes, 70-71.

61 The identity of "worker" in goguette songs was much more complex than these two examples suggest. For a more detailed analysis of this identity, see chapters 3 and 4 of Steven E. Rowe, Literacy Practices of the Laboring Poor in France, 1800-1860 (Ph.D. diss., Duke University, 2002).

62 Rancière recognized problem of male workers' power over wives/women that might be ignored by historians who want to see male workers' texts solely in terms of political critique. See Donald Reid's introduction to The Nights of Labor, xxvii-xxviii, which is based on articles by Rancière in the journal Les Révoltes logiques.

63 Prothero, Radical Artisans, 290-91. Pierre Vinçard, in his contemporary observations of Parisian wokers, also emphasizes the importance of songs for working-class culture more broadly, including giving examples of songs sung by workers while on the job site. See Pierre Vinçard, Les Ouvriers de Paris. Études de Moeurs (Paris: Michel, éd., n.d. [1851]).

64 Claude Duneton has an excellent discussion of this lack of manuscript evidence, and the fact that this does not lead him to conclude that songs were typically not written down. See Claude Duneton, Histoire de la Chanson Française, vol. 2 (Paris: Éditions du Seuil, 1998), 454.

65 For example, see the images in "Le Goguettier," in Les Français Peints par Eux-Mêmes. Encyclopédie Morale du Dix-Neuvième Siècle, vol. 4 (Paris: L. Curmer, 1850), 512-21.

66 For an example of an individual song sheet, see Pierre Brochon, La chanson française (II): Le pamphlet du pauvre. Du Socialism Utopique à la Révolution de 1848 (Paris: Éditions sociales, 1957), 128.

67 Maurice Agulhon makes an argument akin to this in his study of the peasantry in Southern France in the post-Revolutionary period. Agulhon examines folkloric practices and ceremonies that became "contaminated" by politics, seeing these still as essentially "archaic." See Maurice Agulhon, La République au Village: les populations du Var de la Révolution à la Seconde République (Paris: Plon, 1970). 
68 Carnival and charivari were series of folk festivals that were particularly common in sixteenth and seventeenth-century European rural communities but also continued in some forms into the modern period. Such festivals often involved criticism of the social order through farcical representations of the upper classes by the peasantry, as well as periods of gender-role inversion, where women would jokingly criticize men. See Natalie Zemon Davis, Society and Culture in Early Modern France: Eight Essays (Stanford: Stanford University Press, 1975). 